\title{
Evaluation of leaf and root absorptions of glyphosate in the growth of coffee plants
}

\author{
Avaliação da absorção foliar e radicular de glifosato no crescimento de plantas \\ de café
}

\author{
Edimilson Alves Barbosa' (1) (https://orcid.org/0000-0002-9776-3826) \\ Isabel Moreira da Silva2* (10) (https://orcid.org/0000-0001-6861-0102) \\ André Cabral França ${ }^{2}$ (1) (https://orcid.org/0000-0002-9009-3903) \\ Enilson de Barros Silva ${ }^{2}$ (1) (https://orcid.org/0000-0002-2088-9965) \\ Christiano da Conceição de Matos ${ }^{3}$ (1) (https://orcid.org/0000-0002-0385-8737)
}

\begin{abstract}
Intoxication by dispersion of glyphosate droplets in coffee seedlings is common and, in addition to the problem of drift, there are reports of contamination of this herbicide to a nontarget plant via the rhizosphere. Hydroponics allows the comparison of the translocation of the glyphosate absorbed by the foliage or the roots and avoids the interaction with the soil, which could hamper the achievement of more accurate conclusions when it is absorbed by the root. Thus, the toxicity of glyphosate sublethal dosages in the initial growth of coffee plants in hydroponics was evaluated by applying four sublethal dosages in two different locations (solution and leaf). Fifty days after the application of the herbicide, the intoxication percentage and the growth of the coffee seedlings were evaluated. From the reduced dose of $115.2 \mathrm{~g} \cdot \mathrm{ha}^{-1}$ of glyphosate, height reductions, root length; number of leaves, dry mass of leaf, roots and total, leaf area, and leaf mass ratio were observed. The first two parameters were observed only in leaf application and the others via leaf and solution. The aerial part-root ratio system had an increase in herbicide sublethal dosages when applied to leaves and the ratio of leaf area and specific leaf area increased in both applications. Sublethal dosages of glyphosate applied to young coffee plants under hydroponic conditions impair their growth, and it is more accentuated with increasing doses and when the leaves, instead of the roots, absorb the herbicide.
\end{abstract}

KEYWORDS: absorption; Coffea arabica; phytotoxicity; hydroponics.
RESUMO: Intoxicação por dispersão das gotas de glifosato em mudas de café são comuns, além do problema da deriva, há relatos da passagem desse herbicida para planta não alvo via rizosfera. A hidroponia possibilita comparar a translocação do glifosato absorvido pelas folhagens ou raízes e evita a interaçáo do solo que poderia dificultar a obtenção de conclusóes mais precisas quando absorvido pela raiz. Assim, a toxidade de subdoses de glifosato no crescimento inicial de plantas de café em hidroponia foi avaliada aplicando-se quatro subdoses em dois locais distintos (solução e folha). Cinquenta dias após a aplicaçáo do herbicida, a porcentagem de intoxicação e o crescimento das mudas de café foram avaliados. A partir da subdose de 115,2 g.ha-1 de glifosato observaram-se reduçôes da altura; comprimento radicular; número de folhas; massa seca da folha, raiz, radicular e total; área foliar; razão de massa foliar, sendo os dois primeiros parâmetros observados somente na aplicação foliar e os demais via foliar e solução. A relação parte aérea/sistema radicular aumentaram com o incremento das subdoses do herbicida quando aplicado nas folhas e a razâo de área foliar e área foliar específica aumentaram em ambas as vias de aplicação. Subdoses de glifosato aplicadas em plantas jovens de café, em condições hidropônicas, prejudicam o seu crescimento sendo mais acentuados com o aumento das doses e quando o herbicida é absorvido pelas folhas em relaçáo à absorção radicular.

PALAVRAS-CHAVE: absorção; Coffea arabica; fitotoxicidade; hidroponia.

\footnotetext{
'Instituto Federal de Educação Ciência e Tecnologia do Norte de Minas Gerais - Departamento de Agronomia - Almenara (MG), Brazil. ${ }^{2}$ Universidade Federal dos Vales do Jequitinhonha e Mucuri - Programa de Pós-Graduação em Produção Vegetal - Diamantina (MG), Brazil. ${ }^{3}$ Universidade do Estado de Minas Gerais - Departamento de Agronomia - Ituiutaba (MG), Brazil 


\section{INTRODUCTION}

The management of weeds in crops is essential in order to achieve greater productivity (SCHRÜBBERS et al., 2014; COSTA et al., 2017). Coffee trees are sensitive to the interference of invasive plants that, even at low densities, can cause decreases in nutritional content by competing for resources in the environment which makes them scarce for coffee plants and hinders harvesting and treatment (FRANÇA et al., 2010a; CARVALHO et al., 2014). The chemical control of weeds stands out for being more efficient; however, the reduced number of selective products to coffee culture increases the application of no selective herbicides such as glyphosate (SCHRÜBBERS et al., 2014).

Glyphosate [N-(phosphonomethyl) glycine] is one of the most widely used systemic herbicides in weed control due to its broad aspect of action, low cost and low vapor pressure (KRUSE et al., 2000; GREEN, 2007; CAMPOS et al., 2013). Glyphosate inhibits the enzyme 5-enolpyruvylchiquimate-3-phosphate synthase (EPSP) from the metabolic pathway of shikimic acid, therefore preventing the synthesis of essential amino acids such as phenylalanine, tyrosine and tryptophan and secondary metabolites (KRUSE et al., 2000; SCHRÜBBERS et al., 2014). It also compromises metabolic processes such as carbon flow, photosynthesis (GREEN, 2007; GOMES et al., 2016) and the nutritional status of plants (FRANÇA et al., 2010a).

Despite knowing the effects of glyphosate on weeds, it is important to understand about its interference in the growth and development of nontarget plants that even with due care, cases of intoxication due to the dispersion of drops in coffee plants are common (FRANÇA et al., 2010a; CARVALHO et al., 2013). In addition to the drift problem, there are reports of the contamination of herbicide from target plants (weed) to nontarget plants (economic culture) by the rhizosphere and mycorrhizal interactions (WAGNER et al., 2003; SANTOS et al., 2008). ${ }^{14} \mathrm{C}$-glyphosate was found in the tissues of Eucalyptus grandis (Myrtaceae) after the application of the herbicide in plants of Brachiaria decumbens (Gramineae) (SANTOS et al., 2008). However, the effects on growth and development in nontarget crops such as coffee are not known when this herbicide is absorbed by the root system of this plant. Understanding the divergences in glyphosate absorption pathways is important due to its widespread use in the management of weeds in coffee, which can improve the management in agricultural practices. The hydroponic system avoids the interaction of the herbicide with the soil, which could make it more difficult to reach conclusions that are more accurate. Therefore, it can be a method to compare the differential sensitivity of coffee plants by the glyphosate absorbed by the foliage or the roots.
This work aimed to verify the toxicity of glyphosate in coffee seedlings by two absorption routes through the hydroponic system using a nutrient solution containing the herbicide.

\section{MATERIAL AND METHODS}

Coffee seeds of 'Catuaí Vermelho IAC 99' were placed to germinate in a washed sandbox and were transferred to a tray containing $1 / 4$ of the concentration of nutrients for adaptation of the plants in the matchstick phase. Four increasing changes were made weekly until the final concentration of the solution of HOOGLAND; ARNON (1938).

Upon reaching two pairs of fully developed leaves, the seedlings were transferred to pots with $2.0 \mathrm{~L}$ of hydroponic solution. The pots were covered with a $1 \mathrm{~cm}$ thick extruded polystyrene foam (XPS) with a hole for insertion of the root in the solution and another for the entry of the hose that conducted the air.

The plants remained in the pots for one week, and then they received the sublethal dosages of glyphosate $0.0,115.2$, 230.4, and $460.8 \mathrm{~g}^{-h^{-1}}{ }^{-1}$ in the leaves and in the hydroponic solution corresponding to 0 , respectively 8,16 and $32 \%$ of the $1440 \mathrm{~g} \cdot \mathrm{ha}^{-1}$ dose of the isopropylamine salt formulation. In the application, the pots with the seedlings were lined up and each dose applied once with a $\mathrm{CO}_{2}$ pressurized sprayer, calibrated at a constant pressure of $250 \mathrm{kPa}$, equipped with a bar, with a fan-type spray tip (TT 11002), providing the application of $200 \mathrm{~L} \cdot \mathrm{ha}^{-1}$ of syrup.

The design was a randomized block with a 2 by 4 factorial scheme with seven replications, the first one referring to the absorption pathway (leaf and root) and the second one to the sublethal dosages of glyphosate. The experimental unit consisted of a vase with a coffee seedling.

Fifty days after the application (DAA) of the glyphosate, the percentage of intoxication of the coffee plants by the herbicide was evaluated, using a scale from 0 to $100 \%$, where 0 corresponds to the absence of visible symptoms and $100 \%$ to the death of the plants (FRANS, 1972). Then, the plants were collected and leaf area (ANTUNES et al., 2008), collar diameter, height, number of leaves, root length, dry mass of leaf, stem and root were evaluated. From the values obtained, the aerial part-root ratio, leaf area ratio, specific leaf area and the leaf, stem and root mass ratios were calculated according to the following formulas: aerial part-root ratio $\left(\mathrm{g} \cdot \mathrm{g}^{-1}\right)=($ aerial part dry mass/root dry mass); leaf area ratio $\left(\mathrm{cm}^{2} \cdot \mathrm{g}^{-1}\right)=$ (leaf area/total dry mass); specific leaf area $\left(\mathrm{cm}^{2} \cdot \mathrm{g}^{-1}\right)=$ (leaf area/ dry leaf mass); leaf mass ratio $\left(\mathrm{g} \cdot \mathrm{g}^{-1}\right)=($ leaf dry mass/total dry mass); stem mass ratio $\left(\mathrm{g} \cdot \mathrm{g}^{-1}\right)=$ (stem dry mass/total dry mass); root mass ratio $\left(\mathrm{g} \cdot \mathrm{g}^{-1}\right)=$ (root dry mass/total dry mass).

The data were submitted to analysis of variance, and the variables were compared by regression analysis, with the choice 
of models based on their significance, biological phenomenon, and determination coefficient.

\section{RESULTS AND DISCUSSION}

The glyphosate caused intoxication in coffee plants, with increasing values proportional to the increase of sub-lethal dosages and greater intensity when applied to the leaves, reaching

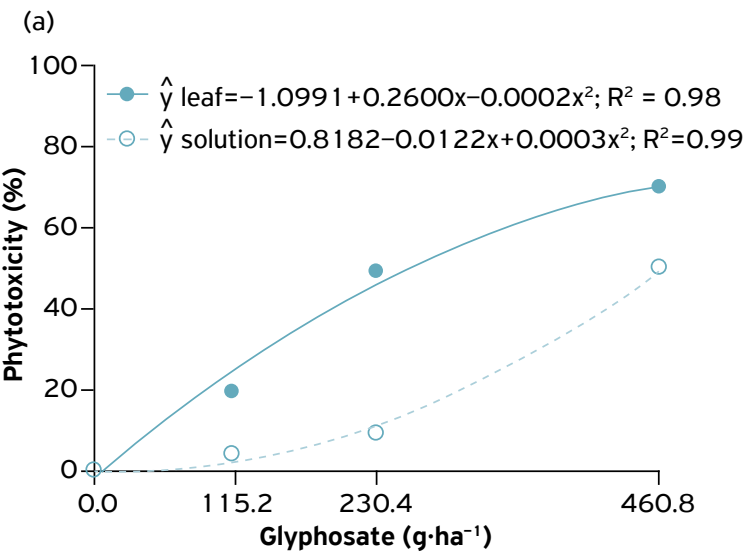

(c)
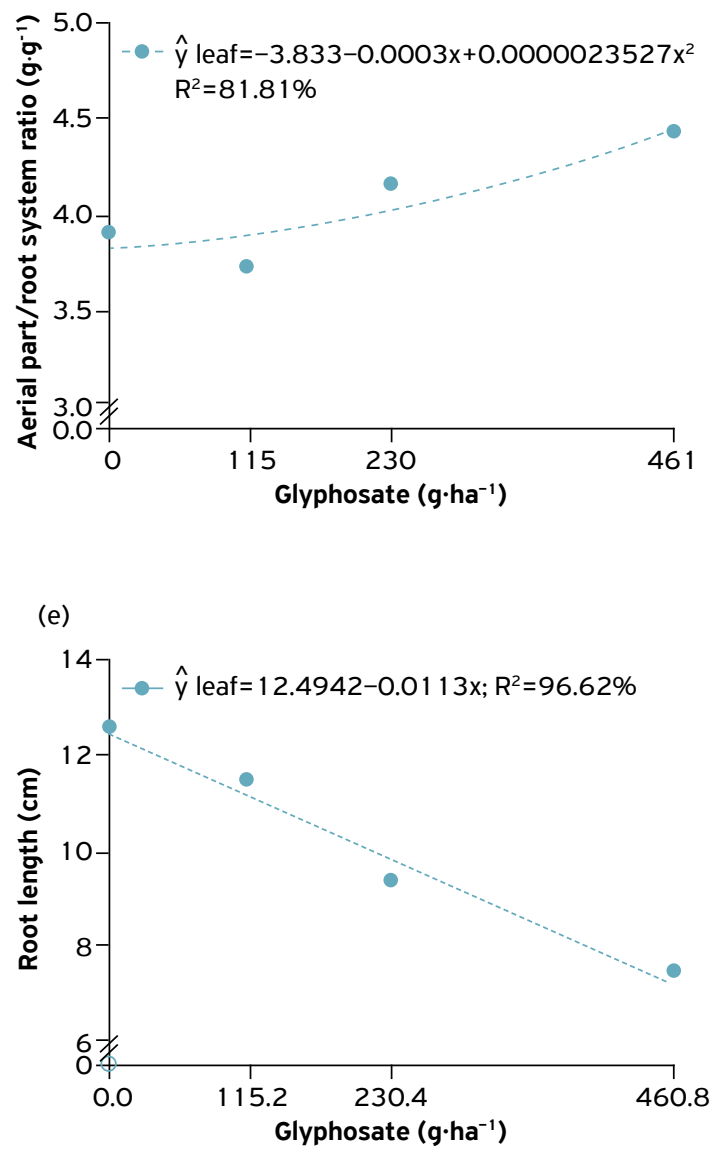

70 and $50 \%$, in 50 DAA via leaf and solution respectively (Fig. 1a). The symptoms observed were narrowing of the leaf blade and internerval chlorosis in new leaves, similar to those reported by other authors (FRANÇA et al., 2010b; SILVA et al., 2016). Internerval chlorosis and narrowing of the leaf blade can occur due to $\mathrm{Mg}$ and $\mathrm{Zn}$ deficiencies respectively (BOTT et al., 2008; FRANÇA et al., 2010a). Glyphosate is a phosphonic acid that acts as a chelator, blocking the absorption of minerals by the plant with high specificity for the micronutrients $\mathrm{Mn}, \mathrm{Fe}, \mathrm{Zn}$ and $\mathrm{Cu}$ (COUTINHO; MAZO,
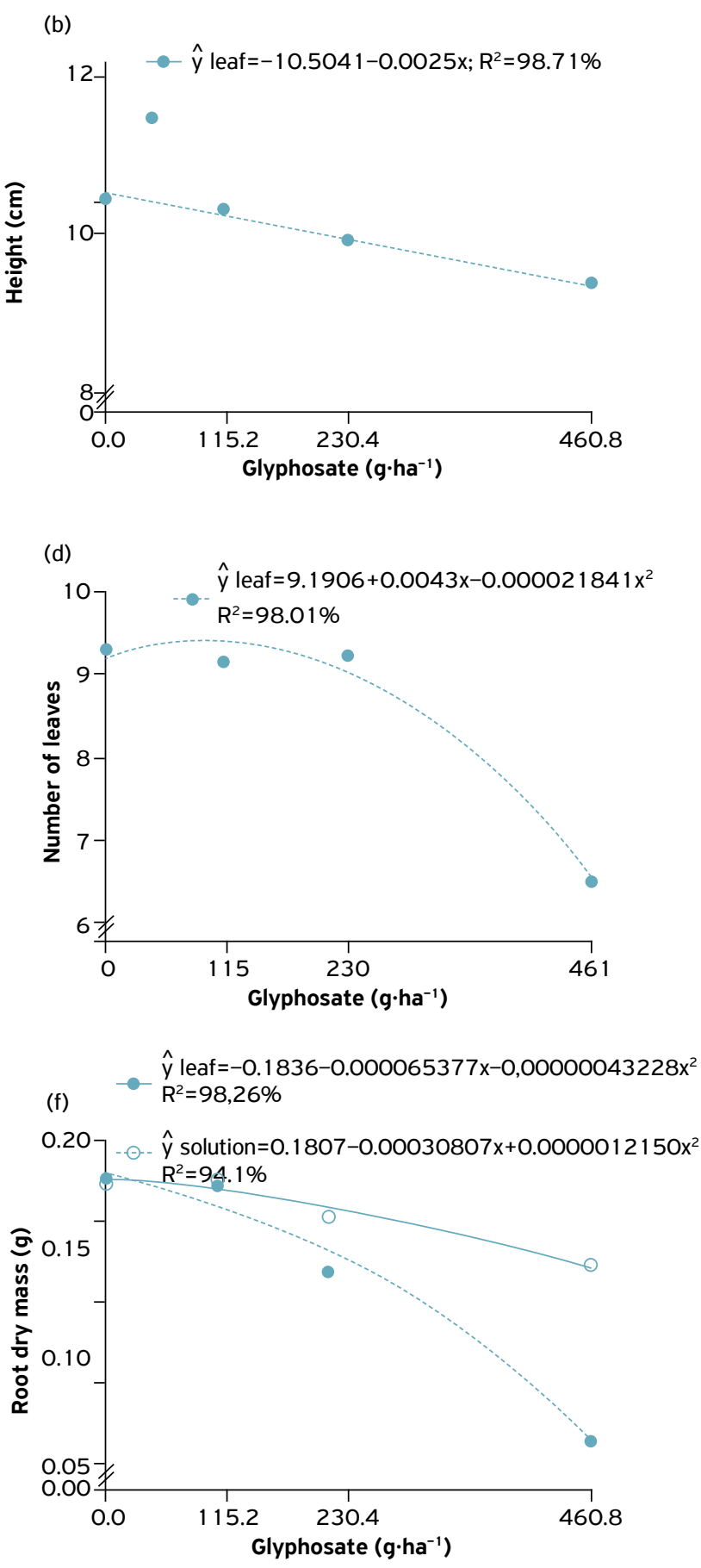

Figure 1. Phytotoxicity (a); height (b); aerial part/root ratio (c); number of leaves (d); root length (e); root dry mass ( $f$ ) of young coffee plants submitted to different doses of glyphosate, 50 days after application. 
2005). Another possible cause of leaf lesion is the accumulation of aminomethylphosphonic acid (AMPA), which is the first metabolite of glyphosate (DING et al., 2011). The lesser effect when applied to the solution may have occurred due to the dilution of the herbicide when applied in the solution, reducing the absorbed concentration.

The stem diameter and stem mass ratio of coffee plants were not altered in 50 DAA with sublethal dosages of glyphosate regardless of the route of application (solution or leaf). A similar result was observed for stem diameter in young coffee plants grown in pots with sublethal dosages of this herbicide (FRANÇA et al., 2010b).

The increase in glyphosate doses linearly reduced the height of the coffee plants by $0.0025 \mathrm{~cm}$ for each gram of the herbicide applied via the leaf, but with no effect when applied to the solution (Fig. 1b). This reduction is possibly related to the fact that glyphosate inhibits the synthesis of auxin, a growth hormone, by inhibiting the tryptophan precursor (CHANG et al., 2016; GREEN, 2007). The lower growth induced by this herbicide may have the consequence of reducing the concentrations of micronutrients in the leaves (FRANÇA et al., 2010a). Different results were observed in peach trees [(Prunus persica (Rosaceae)] (SANTOS et al., 2006) and Varjāo [Parkia multijuga (Leguminosae - Mimosoideae)] (YAMASHITA et al., 2006) in which sublethal dosages of glyphosate did not provide growth suspension, indicating greater sensitivity for young coffee seedlings. Differential tolerance between species to agrochemicals can occur due to differences in applied doses, absorption and translocation to the target site, mechanisms that reduce the absorption of drops such as trichomes, thick layer of wax and overlapping leaves (REDDY et al., 2008; SILVA et al., 2016).

Stimulation of vegetative growth in low doses of toxic substances, known as hormone, was observed for glyphosate (BRITO et al., 2017) characterized by the greater thickness of the spongy parenchyma (SILVA et al., 2016). However, this effect was not observed in the coffee seedlings in any of the absorption routes, regardless of the sublethal dosages applied. The hormone effect is dependent on the plant's growth stage at the time of application, which can lead to different results (CARVALHO et al., 2013; CEDERGREEN, 2008).

The aerial part-root ratio was affected in a quadratic way by the doses of glyphosate (Fig. 1c). Leaf absorption at a dose of $460.8 \mathrm{~g}^{-h a^{-1}}$, observed an increase of $13.86 \%$ compared to the control, but with no effect when applied to the solution regardless of the dose. A different result was observed for barley [(Hordeum vulgare (Poaceae)] in hydroponics with an increase of 10 to $30 \%$ in the root-aerial part ratio (CEDERGREEN, 2008). The decrease in the root length along with the increase in the aerial part indicates a greater investment of photoassimilates for the leaves rather than to the root system (CARVALHO et al., 2014; FRANÇA et al., 2010a; SANTOS et al., 2008). This result suggests that coffee roots may be more affected after glyphosate drift and the distribution of resources in one organ may have priority over another depending on the species.

The number of leaves was influenced by the sublethal dosages of glyphosate with the lowest value in the treatment in which the herbicide was applied to the aerial part, reaching

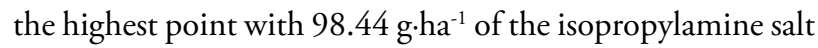
formulation with reduction from the increment of the doses (Fig. 1d). However, reduction in the number of leaves was not observed for the cultivars Catucaí Amarelo, Oeiras and Topázio (FRANÇA et al., 2010b) showing distinct susceptibility among coffee cultivars to sublethal dosages of glyphosate. The smaller number of leaves observed may be related to the lower growth of the plant and the interference in the allocation of resources. Leaf reduction reduces the possibility of maintaining fruit production due to the lower photosynthetic rate and lower carbohydrate fixation (DAMATTA, 2004).

The length and root dry mass of coffee reduced when the glyphosate dosage was increased, with effect on the route of application for the last parameter, where a greater reduction was observed when the herbicide was applied on the leaves (Fig. 1e and f). This is due to the fact that this herbicide is systemic and translocates through the path of photoassimilates from the leaves to the other parts, affecting the growth points such as root meristems (KRUSE et al., 2000). The growth of young plant roots was expanding and presented high cell division; thus, amino acids, hormones or enzymes that participate in these processes may have been inhibited with increased doses of the herbicide due to their translocation to the growth zone (CARVALHO et al., 2014). The presence of glyphosate in the Brachiaria roots was observed by darkening them (SANTOS et al., 2008) and the damage to the cotton roots, in hydroponics, included inhibition of development, deposition of a thick layer of dead cells and cellular exudates (PLINE et al., 2002). If the root system of soil coffee seedlings is affected by glyphosate in a similar way to plants growing in hydroponic environment, the interruption of growth induced by this herbicide at the root can lead to a more severe water stress or a slower development of seedlings.

The dry leaf, stem and total variables had the lowest values when the herbicide was applied to the leaves (Fig. 2a, b and c). Corn plants, in hydroponic solution, were more sensitive to glyphosate in the aerial part than in the root with 12 and 32\% of herbicide accumulated in the apex of this plant when applied via solution and leaf, respectively (ALISTER et al., 2005). There was an effect of the interaction between the variables dry mass of leaves (Fig. 2a), stem (Fig. 2b), roots (Fig. 1e) and total (Fig. 2c) and the increase in glyphosate doses reduced the mass of the coffee plants. Reductions of these parameters were also observed in physic nut plants, Jatropha curcas L. (Euphorbiaceae), treated with sublethal dosages of this herbicide (COSTA et al., 2009). Physiological stress caused shortly after application of glyphosate may have reduced dry mass, as it showed symptoms of injuries, which intensified when 

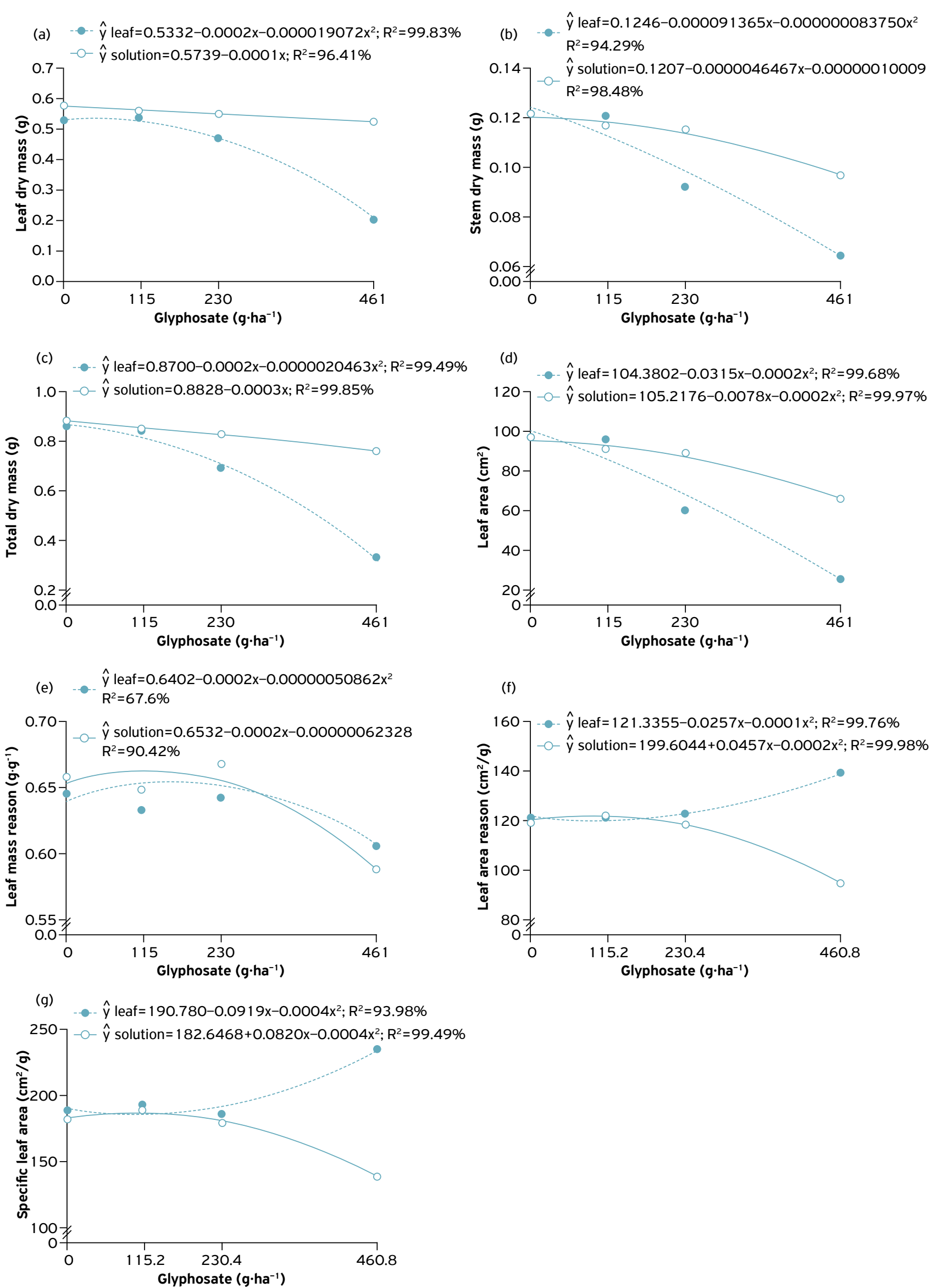

Figure 2. Leaf dry mass (a), stem dry mass (b), total dry mass (c); leaf area (d); leaf mass ratio (e); reason of leaf area (f) and specific leaf area $(\mathrm{g})$ of young coffee plants submitted to different doses of glyphosate, at 50 days after application. 
doses were increased. Glyphosate can interfere with carbon absorption, reducing the accumulation of dry matter and the deregulation of the shikimate pathway, causing a shortage of compounds necessary for carbon fixation, a process that is quickly inhibited (SERVAITES et al., 1987).

The leaf area was reduced in a quadratic way by the doses of glyphosate (Fig. 2d). In the dose of $460.8 \mathrm{~g} \cdot \mathrm{ha}^{-1}$, the lowest values were observed, with $44.77 \mathrm{~cm}^{2}$ in the leaf and $72.11 \mathrm{~cm}^{2}$ in the solution, when compared to the control with an average leaf area of $104.49 \mathrm{~cm}^{2}$. A similar result was observed for the coffee cultivars Topázio, Catucaí and Oeiras (FRANÇA et al., 2010b). This reduction may have been caused by the injuries caused by the herbicide, showing that sublethal dosages cause intoxication of the plants, reflecting less development of the leaves. Reduction of leaf area and number of leaves can decrease the photosynthetic rate and the accumulation of carbohydrates, impairing plant growth (GEIGER; BESTMAN, 1990; DAMATTA, 2004).

The sublethal dosages of glyphosate reduced the leaf mass ratio (LMR), which lowest values were obtained at the dose of $460.8 \mathrm{~g} \cdot \mathrm{ha}^{-1}$ (Fig. 2e), being $0.60 \mathrm{~g} \cdot \mathrm{g}^{-1}$, when the herbicide was applied to the leaves of the plants and $0.59 \mathrm{~g} \cdot \mathrm{g}^{-1}$ when sprayed in solution. Which can be compared to the average of $0.65 \mathrm{~g} \cdot \mathrm{g}^{-1}$ in treatments that did not receive the herbicide. Lower LMR values indicate low allocation of assimilates to the leaves (FALQUETO et al., 2009), suggesting that sublethal dosages of glyphosate compromise the allocation of photoassimilates in the leaves of young coffee plants, causing intoxication and reflecting in less accumulation of dry matter in the leaves. Glyphosate can reduce $\mathrm{CO}_{2}$ fixation, resulting in less carbohydrates exported to the source (GEIGER; BESTMAN, 1990; GEIGER et al., 1999).

The leaf area ratio (LAR) and the specific leaf area (SLA) decreased when glyphosate was absorbed via the root, and presented a quadratic increase when it was absorbed through the air. Which proves it to be more sensitive to interference by the leaf with the increase in the dose of 230.4 to $460.8 \mathrm{~g}^{2} \cdot \mathrm{ha}^{1}$. There were increases of 49.29 and $16.89\left(\mathrm{~cm}^{2} \cdot \mathrm{g}^{-1}\right)$ for SLA and LAR, respectively (Fig. $2 \mathrm{f}$ and g). These two variables correlate with photosynthetic capacity and the source-drain ratio. The increase in SLA may be correlated with lower leaf mass, this is due to leaf weight being a factor for SLA, being inversely proportional to this variable (CANCELLIER et al., 2010). Weight reduction, in addition to the lower carbohydrate accumulation already mentioned, may occur due to injuries, chlorosis and foliar narrowing caused by the herbicide. The decrease in the photosynthetic rate may occur due to the accumulation of shikimic acid caused by the inhibition of its route by glyphosate, which may represent a strong carbon drain in the Calvin cycle, due to the deviation of erythrose-4-phosphate from this route (SHIEH et al., 1991).

Glyphosate was less active in coffee seedlings when captured by the roots and may be related to the absorption path and, when applied to the leaves, it follows the symplast path (GEIGER et al., 1999; BROMILOW; CHAMBERLAIN, 2000) and the root movement is mainly by the apoplast and, eventually, the herbicide enters the symplast (ALISTER et al., 2005). The formation of the cation-glyphosate complex reduces the activity of this herbicide (HALL et al., 2000) and this complex may not be formed in the symplast because the cations create complexes with organic compounds (TAIZ; ZEIGER, 2002), so the activity of the glyphosate by this route may be greater. This may explain the lower toxicity of this herbicide when absorbed by the roots. Another hypothesis is that dilution of glyphosate in solution decreases the availability for absorption, which is different from when it was applied to the leaves.

\section{CONCLUSIONS}

Sublethal dosages of glyphosate applied to young coffee plants under hydroponic conditions impair their growth with market effects when doses were increasing and the herbicide was absorbed by the leaves, rather than root absorption.

ACKNOWLED GEMENTS: The authors thank the Universidade Federal dos Vales do Jequitinhonha e Mucuri and Fundação de Amparo à Pesquisa do Estado de Minas for granting the resources to carry out this study.

FUNDING: Not applicable.

CONFLICTS OF INTEREST: All authors declare that they have no conflict of interest.

ETHICAL APPROVAL: Not applicable.

AVAILABILITY OF DATA AND MATERIAL: All data generated or analyzed during this study are included in this published article.

AUTHORS' CONTRIBUTIONS: Conceptualization: Silva, I.M.; Barbosa, E.A. Methodology: Matos, C.C. Supervision: França, A.C.; Silva, E.B. Writing - original draft: Silva, I.M.; Barbosa, E.A. Writing - review \& editing: Silva, I.M.; Barbosa, E.A. 

REFERENCES

ALISTER, C.; KOGAN, M.; PINO, I. Differential phytotoxicity of glyphosate in maize seedlings following applications to roots or shoot. Weed Research, United Kingdom, v.45, n.1, p.27-32, 2005. https://doi.org/10.1111/j.1365-3180.2004.00424.x

ANTUNES, W.C.; POMPELLI, M.F.; CARRETERO, D.M.; DAMATTA, F.M. Allometric models for non-destructive leaf area estimation in coffee (Coffea arabica and Coffea canephora). Annals of Applied Biology, Newport, v.153, n.1, p.33-40, 2008. https://doi. org/10.1111/j.1744-7348.2008.00235.x

BOTT, S.; TESFAMARIAM, T.; CANDAN, H.; CAKMAK, I.; RÖMHELD, V.; NEUMANN, G. Glyphosate-induced impairment of plant growth and micronutrient status in glyphosate-resistant soybean (Glycine max L.). Plant and Soil, Beijing, v.312, n. 1-2, p.185, 2008. https://doi.org/10.1007/s $11104-008-9760-8$

BRITO, I.P.F.S.; TROPALDI, L.; CARBONARI, C.A.; VELINI, E.D. Hormetic effects of glyphosate on plants. Pest Management Science, Oxford, v.74, n.5, p.1064-1070, 2017.https://doi.org/10.1002/ps.4523

BROMILOW, R.H.; CHAMBERLAIN, K. The herbicide glyphosate and related molecules: physicochemical and structural factors determining their mobility in phloem. Pest Management Science, Oxford, v.56, n.4, p.368-373, 2000. https://doi.org/10.1002/(SICI)15264998(200004)56:4\%3C368::AID-PS153\%3E3.0.CO;2-V

CAMPOS, C.F.; VITORINO, H.S.; SOUZA, G.S.F.; SANTANA, D.C.; MARTINS, D. Translocação dos herbicidas glyphosate e imazamox em plantas de aguapé. Arquivos do Instituto Biológico, São Paulo, v.80, n.2, p.177-182, 2013. https://doi.org/10.1590/ S1808-16572013000200006

CANCELLIER, L.L.; ADORIAN, G.C.; RODRIGUES, H.V.M.; SIEBENEICHLER, S.C.; LEAL, T.C.A.B. Doses de potássio nas respostas morfofisiológicas de alface. Revista Caatinga, Mossoró, v.23, n.4, p.21-27, 2010.

CARVALHO, L.B.; ALVES, P.L.C.A.; DUKE, S.O. Hormesis with glyphosate depends on coffee growth stage. Anais da Academia Brasileira de Ciências, Rio de Janeiro, v.85, n.2, p.813-822, 2013. https://doi.org/10.1590/S0001-37652013005000027

CARVALHO, F.P.; SOUZA, B.P.; FRANÇA, A.C.; FERREIRA, E.A.; FRANCO, M.H.R.; KASUYA, M.C.M.; FERREIRA, F.A. Glyphosate drift affects arbuscular mycorrhizal association in coffee. Planta Daninha, Viçosa, v.32, n.4, p.783-789, 2014. https://doi. org/10.1590/SO100-83582014000400013

CEDERGREEN, N. Is the growth stimulation by low doses of glyphosate sustained over time? Environmental Pollution, Roskilde, v.156, n.3, p.1099-1 104, 2008. https://doi.org/10.1016/j. envpol.2008.04.016

CHANG, J.-D.; HUANG, J.; YASEEN, M.; JIANG, B.; SHEN, Z.; SHI, D.; JIANG, Z.; QI, Z.; LU, H.; LIANG, Z. Photosynthetic characteristics, stress responses and plant growth of Eupatorium adenophorum in response to foliar application of different concentrations of glyphosate. Philippine Agricultural Scientist, Philippines, v.99, n.3, p.267-276, 2016.
COSTA, N.V.; ERASMO, E.A.L.; QUEIROZ, P.A.; DORNELAS, D.F.; DORNELAS, B.F. Efeito da deriva simulada de glyphosate no crescimento inicial de plantas de pinhão-manso. Planta Daninha, Viçosa, v.27, p.1105-1110, 2009. Special Issue. https://doi. org/10.1590/SO100-83582009000500024

COSTA, A.C.R.; GONÇALVES, C.G.; SILVA JÚNIOR, A.C.; CARDOSO, L.; MARTINS, D. Action of rain on formulations of glyphosate mixed with saflufenacil for the control of Brachiaria decumbens. Arquivos do Instituto Biológico, São Paulo, v.84, p.e0172015, 2017. https://doi.org/10.1590/1808-1657000172015

COUTINHO, C.F.B.; MAZO, L.H. Complexos metálicos com o herbicida glifosato: revisão. Química Nova, São Paulo, v.28, n.6, p.1038-1045, 2005. https://doi.org/10.1590/ so $100-40422005000600019$

DAMATTA, F.M. Ecophysiological constraints on the production of shaded and unshaded coffee: a review. Field Crops Research, Netherlands, v.86, n.2-3, p.99-114, 2004. https://doi. org/10.1016/j.fcr.2003.09.001

DING, W.; REDDY, K.N.; ZABLOTOWICZ, R.M.; BELLALOUI, N.; BRUNS, H.A. Physiological responses of glyphosate-resistant and glyphosate-sensitive soybean to aminomethylphosphonic acid, a metabolite of glyphosate. Chemosphere, Amsterdam, v.83, n.4, p.593-598, 2011 . https://doi.org/10.1016/j. chemosphere.2010.12.008

FALQUETO, A.R.; CASSOL, D.; MAGALHÃES JÚNIOR, A.M.; OLIVEIRA, A.C.; BACARIN, M.A. Crescimento e partição de assimilados em cultivares de arroz diferindo no potencial de produtividade de grãos. Bragantia, Campinas, v.68, n.3, p.563-571, 2009. https://doi.org/10.1590/S0006-87052009000300002

FRANÇA, A.C.; FREITAS, M.A.M.; D'ANTONINO, L.; FIALHO, C.M.T.; SILVA, A.A.; REIS, M.R.; RONCHI, C.P. Teores de nutrientes em cultivares de café arábica submetidos à deriva de glyphosate. Planta Daninha, Viçosa, v.28, n.4, p.877-885, 2010a. https:// doi.org/10.1590/SO100-83582010000400021

FRANÇA, A.C.; FREITAS, M.A.M.; FIALHO, C.M.T.; SILVA, A.A.; REIS, M.R.; GALON, L.; VICTORIA FILHO, R. Crescimento de cultivares de café arábica submetidos a doses do glyphosate. Planta Daninha, Viçosa, v.28, n.3, p.599-607, 201 Ob. https://doi.org/10.1590/ so $100-83582010000300017$

FRANS, R.E. Measuring plant response. In: WILKINSON, R.E. (ed.). Research methods in weed science. Westminster: Southern Weed Science Society, 1972. p.28-41.

GEIGER, D.R; BESTMAN, H.D. Self-limitation of herbicide mobility by phytotoxic action. Weed Science, Cambridge, v.38, n.3, p.324329, 1990. https://doi.org/10.1017/S0043174500056599

GEIGER, D.R.; SHIEH, W.-J.; FUCHS, M.A. Causes of self-limited translocation of glyphosate in Beta vulgaris plants. Pesticide Biochemistry and Physiology, Massachusetts, v.64, n.2, p.124-133, 1999. https://doi.org/10.1006/pest.1999.2419 
GOMES, M.P.; LE MANAC'H, S.G.; MACCARIO, S.; LABRECQUE, M.; LUCOTTE, M.; JUNEAU, P. Differential effects of glyphosate and aminomethylphosphonic acid (AMPA) on photosynthesis and chlorophyll metabolism in willow plants. Pesticide Biochemistry and Physiology, Massachusetts, v. 130, p.65-70, 2016. https:// doi.org/10.1016/j.pestbp.2015.11.010

GREEN, J.M. Review of glyphosate and Als-inhibiting herbicide crop resistance and resistant weed management. Weed Technology, Fayetteville, v.21, n.2, p.547-558, 2007. https:// doi.org/10.1614/WT-06-004.1

HALL, G.J.; HART, C.A.; JONES, C.A. Plants as sources of cations antagonistic to glyphosate activity. Pest Management Science, Oxford, v.56, n.4, p.351-358, 2000. https://doi.org/10.1002/ (SICl)1526-4998(200004)56:4<351::AID-PS151>3.0.CO;2-A

HOOGLAND, D.R.; ARNON, D.I. The water culture method for growing plants without soil. Circular 347. Berkeley: University of California, College of Agriculture, Agricultural Experiment Station, 1938. 39p

KRUSE, N.D.; TREZZI, M.M.; VIDAL, R.A. Herbicidas inibidores da EPSPs: revisão de literatura. Revista Brasileira de Herbicidas, v. 1 , n.2, p.139-146, 2000. https://doi.org/10.7824/rbh.v 1 i 2.328

PLINE, W.A.; WILCUT, J.W.; EDMISTEN, K.L.; WELLS, R. Physiological and morphological response of glyphosate-resistant and nonglyphosateresistant cotton seedlings to root-absorbed glyphosate. Pesticide Biochemistry and Physiology, Massachusetts, v.73, n. 1, p.48-58, 2002. https://doi.org/10.1016/S0048-3575(02)00014-7

REDDY, K.N.; RIMANDO, A.M.; DUKE, S.O.; NANDULA, V.K. Aminomethylphosphonic Acid accumulation in plant species treated with glyphosate. Journal of Agricultural and Food Chemistry, Munich, v.56, n.6, p.2125-2130, 2008. https://doi.org/10.1021/ jfO72954f

SANTOS, L.D.T.; WAGNER JÚNIOR, A.; SILVA, J.O.C.; PIMENTEL, L.D.; SANTOS, C.E.M.; BRUCKNER, C.H.; FERREIRA, F.A. Deriva de herbicidas e efeito de fungicida $X$ herbicida em plantas jovens de pessegueiro. Planta Daninha, Viçosa, v.24, n.3, p.505-512, 2006. https://doi.org/10.1590/SO100-83582006000300012
SANTOS, L.D.T.; SANTOS, J.B.; FERREIRA, F.A.; OLIVEIRA, J.A.; BENTIVENHA, S.; MACHADO, A.F.L. Exsudação radicular de glyphosate por Brachiaria decumbens e seus efeitos em plantas de eucalipto. Planta Daninha, Viçosa, v.26, n.2, p.369-374, 2008. https://doi.org/10.1590/S0100-83582008000200013

SCHRÜBBERS, L.C.; VALVERDE, B.E.; SORENSEN, J.C.; CEDERGREEN, N. Glyphosate spray drift in Coffea arabica Sensitivity of coffee plants and possible use of shikimic acid as a biomarker for glyphosate exposure. Pesticide Biochemistry and Physiology, Massachusetts, v. 1 15, p.15-22, 2014. https://doi. org/10.1016/j.pestbp.2014.08.003

SERVAITES, J.C.; TUCCI, M.A.; GEIGER, D.R. Glyphosate effects on carbon assimilation, ribulose bisphosphate carboxylase activity, and metabolite levels in sugar beet leaves. Plant Physiology, Rockville, v.85, n.2, p.370-374, 1987. https://doi.org/10.1104/ pp.85.2.370

SHIEH, W.-J.; GEIGER, D.R., SERVAITES, J.C. Effect of $\mathrm{N}$-(phosphonomethyl)glycine on carbon assimilation and metabolism during a simulated natural day. Plant Physiology, Rockville, v.97, n.3, p.1109-1114, 1991. https://doi. org/10.1104/pp.97.3.1109

SILVA, L.Q; JAKELAITIS, A.; VASCONCELOS FILHO, S.C.; COSTA, A.C.; ARAÚJO, A.C.F. Morpho-anatomical changes of pequi leaves (Caryocar brasiliense Cambess.) exposed to simulated drift of glyphosate. Revista Árvore, Viçosa, v.40, n.4, p.669-677, 2016. https://doi.org/10.1590/0100-67622016000400010

TAIZ, L.; ZEIGER, E. Assimilation of mineral nutrients. In: Plant Physiology. Sunderland: Sinauer Associates, 2002. p.259-282

WAGNER, R.; KOGAN, M.; PARADA, A.M. Phytotoxic activity of root absorbed glyphosate in corn seedlings (Zea mays L.). Weed Biology and Management, Japan, v.3, n.4, p.228-232, 2003. https://doi.org/10.1046/j.1444-6162.2003.00110.x

YAMASHITA, O.M.; VIEIRA, R.G.; SANTI, A.; RONDON NETO, R.M.; ALBERGUINI, S.E. Resposta de varjão (Parkia multijuga) a subdoses de glyphosate. Planta Daninha, Viçosa, v.24, n.3, p.527-531, 2006. https://doi.org/10.1590/SO100-83582006000300015 